\title{
The effect of cathode materials on the electrochemical reduction of nitric acid
}

\author{
D. Vasudevan \\ Central Electrochemical Research Institute, Karaikudi 630006, Tamilnadu, India, e-mail: vasudevand@rediffmail.com
}

\begin{abstract}
Electrochemical or chemical reduction of nitric acid is a well studied area in literature due to the importance of the products formed. The present work focuses on the effect of conventional cathode materials including $\mathrm{PbO}_{2}$, amalgamated $\mathrm{Cu}$, graphite, $\mathrm{Pb}, \mathrm{Pt}$ and a modified electrode material $\mathrm{Ti} / \mathrm{TiO}_{2}$ on the reduction of nitric acid. Ammonia and hydroxylamine are the main products which are estimated by conventional titration methods. Other conditions being similar, the product distribution varies quite drastically as a function of the electrode material and $\mathrm{Ti} / \mathrm{TiO}_{2}$ is found to favor a higher ratio of hydroxylamine to ammonia formation compared to other electrodes. The conditions have also been optimized based on the maximum yield of the product.
\end{abstract}

Keywords: Electroreduction, Nitric acid, Hydroxylamine, Ammonia, Conventional and modified cathodes, Mechanism.

\section{INTRODUCTION}

The action of metal on nitric acid yields different products namely nitrous acid, hypo nitrous acid, hydroxylamine and ammonia. Electrolytic reduction of nitrates in neutral and alkaline media yields nitrite and ammonia as the chief products. Nitrogen and oxides of nitrogen have also been detected but only small amounts of hydroxylamine have been discovered. As nitrogen has oxidation states from +5 to -3 , the transition from nitrate to nitrogen can give a large number of by-products such as $\mathrm{NO}_{2}, \mathrm{NO}_{2}$, $\mathrm{NO}, \mathrm{N}_{2} \mathrm{O}, \mathrm{NH}_{2} \mathrm{OH}, \mathrm{NH}_{3}, \mathrm{NH}_{2} \mathrm{NH}_{2}$. In addition, some intermediates such as: $\mathrm{H}_{2} \mathrm{~N}_{2} \mathrm{O}_{3}$, $\mathrm{HNO}$ (or its dimer $\mathrm{H}_{2} \mathrm{~N}_{2} \mathrm{O}_{2}$ ) and $\mathrm{NH}_{2} \mathrm{NO}_{2}$, whose stability depends on the solution $\mathrm{pH}$ and the temperature may be involved in the reduction mechanism ${ }^{1-9}$.

Electrolytic reduction of nitric acid at mercury cathode favors hydroxylamine formation but if mercurous sulphate is added, then nitric oxide is obtained with $70 \%$ current efficiency. Hydroxylamine and ammonia are the major products when a mixture of nitric acid and sulphuric acid is electrolyzed. The product efficiency was dependent on the concentration of nitric and sulphuric acids. Amalgamated lead, tin and copper also enhance the yields of hydroxylamine. With $0.4 \mathrm{~g}$ of nitric acid in $50 \%$ sulphuric acid and a current density of $0.0024 \mathrm{~A} / \mathrm{cm}^{2}$, highest current efficiency of $82 \%$ for hydroxylamine formation was observed at amalgamated lead cathode. At mercury as well as at tin or copper amalgams, equally good results were obtained with the enhanced yield of hydroxylamine. The electro osmotic method using ceramic diaphragm yielded $72.8 \%$ hydroxylamine. With stationary cathodes of $\mathrm{Sn}, \mathrm{Pb}, \mathrm{Al}, \mathrm{Fe}, \mathrm{Ni}, \mathrm{Cu}$ or Pt, ammonia was the main product.

The present work was carried out to explore the effect of different cathode materials other than mercury and amalgamated mercury on the product distribution. The aim was to explore an alternate electrode material which can be as efficient under normal experimental conditions (without using higher temperatures, catalysts etc.) but is also nontoxic. Apart from conventional electrode materials, modified electrode $\mathrm{Ti} / \mathrm{TiO}_{2}$ has been used for the first time for any inorganic reduction. It has been previously used as an efficient electrocatalytic cathode for several organic reductions $\mathbf{1 0}^{\mathbf{1 0}}$. It may be mentioned that hydroxylamine is an industrially useful product useful in making caprolactam, nylon intermediate.

\section{EXPERIMENTAL}

The $\mathrm{Ti} / \mathrm{TiO}_{2}$ cathode employed was prepared by the procedure reported in literature ${ }^{13}$. Amalgamated copper/ lead are prepared by immersing a fine sheet in mercury until it is deposited uniformly on the copper/ lead sheet.

Nitric acid and sulphuric acid of AR grade were used. Double distilled water was employed for all the studies.

A nitric acid - sulphuric acid mixture of varying compositions was employed as the catholyte which was placed in a one liter beaker. A $20 \%$ sulphuric acid solution was used as the anolyte which was placed in a ceramic porous pot placed inside the beaker. The cathode and anode $(\mathrm{Pt})$ were placed in the respective compartments. A glass stirrer rotated using a magnetic motor was used for stirring of the solution. This set up was surrounded by the ice bath to maintain constant temperature. A constant current was applied through a regulated DC power supply (Aplab L 3220). The current density at the cathode was maintained at $5.3 \mathrm{~A} / \mathrm{dm}^{2}$. The cell voltage was measured using a multimeter.

The products of electroreduction of nitric acid, namely, hydroxylamine and ammonia were determined volumetrically as follows:

\section{Determination of hydroxylamine by Raschig method}

$50 \mathrm{ml}$ of the reaction mixture is taken for the analysis of hydroxylamine. To the reaction mixture, $30 \mathrm{ml}$ of cold saturated solution of ferric ammonium sulphate (alum) is added followed by $10 \mathrm{ml}$ of diluted $\mathrm{H}_{2} \mathrm{SO}_{4}$ (1:4). The solution is heated to boiling, then diluted to $300 \mathrm{ml}$ and titrated immediately with standard potassium permanganate solution.

\section{Determination of ammonia}

The ammonia content is determined by back titration. The neutralized solution is taken in a round bottom flask fitted with the water condenser; another round bottom 
flask is taken as a receiver which contains excess $0.1 \mathrm{~N}$ $\mathrm{HCl}$ solutions. Then the neutralized solution is boiled for one hour and the stream of ammonia is collected in the receiver. The excess acid in the receiver is then titrated against $0.1 \mathrm{~N} \mathrm{NaOH}$ using methyl orange as indicator. The mole of ammonia is obtained from the difference between the known amount of $\mathrm{HCl}$ added and the moles determined by titration.

\section{RESULTS AND DISCUSSION}

Initially the experiments were optimized based on varying the nitric acid concentration, temperature and sulphuric acid concentration and choosing the best conditions wherein higher yield of hydroxylamine is formed. Under this condition, the experiments were carried out varying the cathode materials.

The effect of cathode materials on the reduction of nitric acid can be seen from Table 1 . It can be seen from the table that ammonia was the main product in all the cases with very small quantity of hydroxylamine being formed. However, compared to electrodes like $\mathrm{PbO}_{2}$, amalgamated $\mathrm{Cu}$, graphite, $\mathrm{Pb}$ and $\mathrm{Pt}$, the amount of hydroxylamine formed at $\mathrm{Ti} / \mathrm{TiO}_{2}$ is considerably higher. It is likely that this electrode favors the formation of hydroxylamine to some extent. While hydroxylamine is formed by 6 electron reduction, ammonia is formed by an 8 electron reduction as shown below in equations 1 and 2:

$\mathrm{HNO}_{3}+6 \mathrm{H}^{+}+6 \mathrm{e}^{-} \rightarrow \mathrm{NH}_{2} \mathrm{OH}+2 \mathrm{H}_{2} \mathrm{O}$

$\mathrm{HNO}_{3}+8 \mathrm{H}^{+}+8 \mathrm{e}^{-} \rightarrow \mathrm{NH}_{3}+3 \mathrm{H}_{2} \mathrm{O}$

While at other electrodes, the hydroxylamine conversion to ammonia is favored and can't be prevented, the Ti/ $\mathrm{TiO}_{2}$ cathode facilitates hydroxylamine formation to some extent. It is likely that the $\mathrm{TiO}_{2}$ layer exhibits catalytic effects. A partial reduction of $\mathrm{TiO}_{2}$ could also be part of the electrocatalytic mechanism similar to the catalysis by $\mathrm{TiO}_{2}$ in organic reductions ${ }^{\mathbf{1 0} \mathbf{- 1 2}}$ as suggested below:

$\mathrm{TiO}_{2}+\mathrm{H}_{2} \mathrm{O}+\mathrm{H}++\mathrm{e}^{-} \rightleftharpoons \mathrm{Ti}(\mathrm{OH})_{3}$

$3 \mathrm{Ti}(\mathrm{OH})_{3}+\mathrm{NO} \rightarrow 3 \mathrm{TiO}_{2}+\mathrm{RNH}_{2} \mathrm{OH}+3 \mathrm{H}_{2} \mathrm{O}$

The electrochemically formed $\mathrm{Ti}^{3+}$ by the reduction of $\mathrm{Ti}^{4+}$ in step 3 reduces $\mathrm{NO}$, one of the intermediates of $\mathrm{HNO}_{3}$ reduction, to $\mathrm{NH}_{2} \mathrm{OH}$ and itself getting oxidized to $\mathrm{Ti}^{4+}$ (Step 4). The $\mathrm{Ti}^{4+} / \mathrm{Ti}^{3+}$ redox couple acts catalytically as shown above and is responsible for higher yields of $\mathrm{NH}_{2} \mathrm{OH}$ formed while using this cathode material.

Further work would be done to increase hydroxylamine formation.

While mercury is toxic, still it has high hydrogen over potential and favors hydroxylamine formation without reducing it further to ammonia. However, the electrode materials in the present study give ammonia as the major product. $\mathrm{Ti} / \mathrm{TiO}_{2}$ however give considerable amount of hydroxylamine and so is the most promising electrode with respect to hydroxylamine formation. Further optimization of the conditions would be undertaken to further enhance hydroxylamine formation.

\section{CONCLUSION}

Electroreduction of nitric acid in sulphuric acid medium results in the formation of ammonia with a small amount of hydroxylamine at $\mathrm{PbO}_{2}$, amalgamated $\mathrm{Cu} / \mathrm{Pb}$, platinum and graphite. $\mathrm{Ti} / \mathrm{TiO}_{2}$ electrode however, favors higher yields of hydroxylamine, a more useful industrial product. In this case, the $\mathrm{Ti}^{4+} / \mathrm{Ti}^{3+}$ redox couple catalyses hydroxylamine formation. Further optimization of reaction conditions to produce higher yields of hydroxylamine is being attempted. The purpose would be to replace the toxic mercury cathode by the $\mathrm{Ti} / \mathrm{TiO}_{2}$ electrode if encouraging results are obtained.

\section{ACKNOWLEDGEMENTS}

I would like to thank N.S.Raghavendran, Scientist, CECRI, for fruitful discussion.

\section{LITERATURE CITED}

1. Encyclopedia of Electrochemistry (2006) Vol. 7a, Inorganic chemistry, Wiley-VCH Verlag $\mathrm{GmbH} \& \mathrm{Co}$, Weinheim, ISBN: 978-3-527-30399-1.

2. Tafel, J., Boerner, K. \& Reindl, L. (1902), Cathodic Polarisation In Diluted Sulphuric Acid , Z. Anorg. Allgem. Chern. 31: 289 - 325.

3. Mellor, J.W. (1939), Mellor's Modern Inorganic chemistry research, Longmans Green, London.

4. Glasstone, S. \& Hickling, A. (1936) Electrolytic Oxidation and Reduction: Inorganic and Organic, Van Nostrand, New York.

5. Dotson, R.L. \& Hernandez, D.Y., US Patent 4,849,073 (1989).

6. Buchholz, J.R \& Powell, R.E.(1963), The Decomposition of Hyponitrous Acid. I. The Non-chain Reaction, J. Am. Chem. Soc., 85 (5): 509 - 511, DOI: 10.1021/ja00888a004

7. Khomutov, N.E. \& Stamkulov, U.S. (1971), Nitrate reduction at various metal electrodes, Sov. Electrochem. 7: 312 $-316$.

8. Shah, H.C. (1982) Fundamental and applied electrochemistry, Society for Advancement of Electrochemical Science and Technology, Bombay.

9. Udupa, H.V.K. \& Narasimham, K.C., (1960), Industrial Application Of Lead Dioxide Electrodes, I Indian Chem Eng, 2: 66.

10. Vasudevan, D. \& Anantharaman, P.N. (1996), Indirect reduction of o- and $\mathrm{m}$-nitrobenzoic acids at a $\mathrm{Ti} /$ ceramic

Table 1. The effect of cathode materials on the electroreduction of nitric acid in $20 \%$ sulphuric acid $\left(\right.$ Anode $\mathrm{Pt}, T /{ }^{\circ} \mathrm{C}=18$; Current density $\mathrm{A} / \mathrm{dm}^{2}=5.3$ )

\begin{tabular}{|l|l|c|c|c|c|c|}
\hline $\mathrm{S}$ & Cathode & $\begin{array}{c}\mathrm{HNO}_{3} \\
\mathrm{~g} / \mathrm{l}\end{array}$ & $\begin{array}{c}\text { Current } \\
/ \mathrm{A}\end{array}$ & $\begin{array}{c}\text { Voltage } \\
/ \mathrm{V}\end{array}$ & $\begin{array}{c}\mathrm{CE}^{*} \text { for } \\
\mathrm{NH}_{3} \\
\%\end{array}$ & $\begin{array}{c}\mathrm{CE}^{*} \text { for } \mathrm{NH}_{2} \mathrm{OH} \\
\%\end{array}$ \\
\hline 1 & $\mathrm{PbO}_{2}$ & 50 & 1.65 & 3.6 & 59.7 & 0.26 \\
\hline 2 & Amalgamated $\mathrm{Cu}$ & 50 & 0.60 & 3.4 & 59.0 & 0.33 \\
\hline 3 & Graphite & 50 & 2.47 & 4.5 & 53.0 & 0.60 \\
\hline 4 & Amalgamated $\mathrm{Pb}$ & 50 & 0.65 & 3.8 & 64.6 & 0.90 \\
\hline 5 & $\mathrm{Pt}$ & 50 & 1.29 & 4.0 & 60.2 & 1.59 \\
\hline 6 & $\mathrm{Ti} / \mathrm{TiO}_{2}$ & 50 & 2.05 & 3.2 & 52.7 & 15.3 \\
\hline
\end{tabular}

${ }^{*} \mathrm{CE}$ : current efficiency 
$\mathrm{TiO}_{2}$ cathode, J Appl Electrochem, 26:767 - 769, DOI 10.1007/ BF00241519.

11. Vasudevan, D. (1995), Reduction of maleic acid at a Ti/ ceramic $\mathrm{TiO}_{2}$ cathode, $J$ Appl Electrochem, 25:176 - 178, DOI 10.1007/BF00248176.

12. Vasudevan, D. \& Kennady, C.J. (2008), Electroreduction of carbonyl compounds at a Ti/ceramic $\mathrm{TiO}_{2}$ cathode, J. Appl. Electrochem. 38:403 - 408, DOI: 10.1007/s10800-007-9452-8.

13. Beck, F. \& Gabriel, W. (1985), Heterogeneous Redox Catalysis on $\mathrm{Ti} / \mathrm{TiO}_{2}$ Cathodes - Reduction of Nitrobenzene, Angew Chem. Int. Ed., 24: 771 / 772, DOI: 10.1002/ anie.198507711. 